\title{
Recent declines of black abalone Haliotis cracherodii on the mainland coast of central California
}

\author{
Jessica M. Altstatt ${ }^{1}$, Richard F. Ambrose ${ }^{2, *}$, John M. Engle $^{1}$, Peter L. Haaker ${ }^{3}$, \\ Kevin D. Lafferty ${ }^{1}$, Peter T. Raimondi ${ }^{4}$ \\ 'Marine Science Institute, University of California, Santa Barbara, California 93106, USA \\ ${ }^{2}$ Environmental Science and Engineering Program, University of California, 10833 Le Conte Avenue, Los Angeles, \\ California 90095-1772, USA \\ ${ }^{3}$ California Department of Fish and Game, Marine Resources Division, 330 Golden Shore, Suite 50, Long Beach, \\ California 90802, USA \\ ${ }^{4}$ Department of Biology, University of California, Santa Cruz, California 95064, USA
}

\begin{abstract}
The black abalone Haliots cracherodii was once abundant in many intertidal habitats in southern California, USA. Beginning in 1985, however, black abalone in southern Californı suffered mass mortalities attributed to a condition termed withering syndrome. The mass mortalities and withering syndrome were confined to southern California except for Diablo Cove, $70 \mathrm{~km}$ north of Point Conception, where mortalities were limited to the immediate vicinity of a warm-water discharge. Beginning in 1992, we monitored 5 locations along the mainland coast of central California to determine whether mass mortalities of black abalone would occur there. Abalone numbers decreased at the 3 southern sites but not at the 2 northern sites. The decline was greatest at the southernmost site, Government Point (near Point Conception), where there was a $97 \%$ reduction in numbers between 1992 and 1995. The 2 sites immediately upcoast of Government Point, Boathouse and Point Arguello, experienced a 39 to $46 \%$ decline, while the 2 northernmost sites (Stairs and Purisima) experienced a slight increase in abalone. All abalone size classes declined at Government Point, Boathouse and Point Arguello, indicating the decline was not caused by overharvesting. Symptoms of withering syndrome, assessed by pulling on individuals, were noted at Boathouse and Point Arguello. Withering syndrome was also detected in the final survey at Stairs, as was a slight decline in abalone abundance, suggesting that mass mortalities may be beginning there. Our observations demonstrate that widespread mass mortality associated with withering syndrome has reached central California and is progressing northward from Point Conception
\end{abstract}

KEY WORDS: Abalone $\cdot$ Rocky intertidal $\cdot$ Population decline $\cdot$ Central California $\cdot$ Mass mortalities

\section{INTRODUCTION}

Black abalone was considered an undesirable species suitable only for bait for most of the present century (Cox 1962), until declines in the stocks of other, more desirable species of abalone combined with the great abundance of black abalone at islands off the coast of southern California, USA, led to the development of a valuable commercial export fishery in 1968.

-Addressee for correspondence. E-mail: rambrose@ucla.edu
This fishery, like the majority of other abalone fisheries, saw a rapid rise, which peaked in 1973, and a decline in harvest tonnage (Parker et al. 1992). Black abalone were virtually eliminated along the mainland coast of southern California, apparently due to heavy fishing pressure, expanding coastal development and pollution (Young 1964, Haaker et al. 1986, Tegner 1989, Shepherd \& Breen 1992, Miller \& LawrenzMiller 1993).

Since the mid 1980s, the once-abundant black abalone has also practically disappeared from the northern Channel Islands off southern California. Harvest- 
ing is unlikely to have caused the observed declime in densities; although the commercial fishery was intensive, regulations forbade taking this species without the use of snorkeling or diving gear, creating a refuge for abalone in the upper intertidal. In response to the virtual collapse of the black abalone stock, the California Department of Fish and Game closed the commercial fishery for black abalone at Santa Barbara, Anacapa and Santa Cruz Islands in 1991 and extended the moratorium to both commercial and sport harvesting throughout California in fall 1993.

A mysterious terminal condition, termed withering syndrome, appears to be the cause of the catastrophic decline in black abalone at the Channel Islands. Withering syndrome symptoms include an atrophied foot muscle, discoloration of the epipodium, reduced activity and inability to adhere tightly to the substratum. In 1985 , commercial fishermen saw moribund black abalone and many empty shells on the southern shore of Santa Cruz Island (Lafferty \& Kuris 1993). Shortly thereafter, in 1986, biologists noted withering syndrome at Anacapa Island (Haaker et al. 1992). Subsequent surveys noted declines in abundances throughout the Channel Islands (Douros 1987, Tissot 1991, 1995, Haaker et al. 1992, Richards \& Davis 1993, VanBlaricom et al. 1993). In most cases, the reduction in numbers was associated with clear signs of withering syndrome. Because co-occurring species did not change significantly (Richards \& Davis 1993), it appeared that declines were restricted to black abalone. Declines were not attributable to harvesting because all size classes decreased in abundance (Parker et al, 1992). Although explanations for the mass mortalities included environmental changes (Davis et di. 1992), such as warm-water El NiñoSouthern Oscillation events (Tissot 1988, 1990, 1995), the pattern of geographic and temporal spread of withering syndrome best supported an infectious disease process independent of environmental factors (Lafferty \& Kuris 1993). Warm temperature, although not associated with the initiation of withering syndrome, was associated with increased rates of mortality (Lafferty \& Kuris 1993). Recently, Gardner et al. (1995) reported an association between withering syndrome and rickettsia-like prokaryotes that infect the digestive tract of apparently diseased abalone (VanBlaricom et al. 1993). Possible pathogen vectors

such as ectoparasitic pycnogonids have been associated with moribund abalone (Richards \& Davis 1993). The late spread to (and slower die off at) San Miguel Island, the most northern of the Channel Islands, suggested that cooler temperatures or oceanographic currents might prevent the spread of withering syndrome north of Point Conception (Richards \& Davis 1993). In 1988, however, researchers at Pacific Gas and Electric Diablo Canyon Power Plant (approximately $70 \mathrm{~km}$ north of Point Conception) reported moribund black abalone with symptoms similar to those at the Channel Islands. These die-offs appeared to be restricted to the immediate vicinity of the power plant's thermal discharge within Diablo Cove, where water temperatures were elevated $10^{\circ} \mathrm{C}$ above ambient waters, and quickly led to population reductions of greater than $90 \%$ at some sites (Steinbeck et al. 1992). Withering syndrome was not evident in the cooler waters outside of the cove. 
To determine if withering syndrome and the mass mortalities would become widespread along the mainland coast, we monitored black abalone in central California (Fig. 1). In 1988, the California Department of Fish and Game established a permanent site near Point Arguello specifically to monitor black abalone populations. Four additional sites were established in Santa Barbara County, California, in late 1991 to detect changes in the abundances of key species, including black abalone (Ambrose et al. 1995). After almost 4 yr of monitoring, our data indicate that substantial declines in abalone density occurred at the 3 southernmost sites in a temporal pattern consistent with a northerly spread of withering syndrome.

\section{METHODS}

We monitored black abalone at 5 sites in northern Santa Barbara County (Fig. 1). We chose our sites where abalone were numerous and the intertidal area was accessible and suitable for establishing permanent plots. All sites were subjected to some sport (but not commercial) harvesting, but accessibility to fishermen varied from site to site. The southernmost site, Government Point $\left(34^{\circ} 26.62^{\prime} \mathrm{N}, 122^{\circ} 27.32^{\prime} \mathrm{W}\right)$, was on private land. All other sites were within Vandenberg Air Force Base. At Boathouse $\left(34^{\circ} 33.17^{\prime} \mathrm{N}, 122^{\circ}\right.$ $36.37^{\prime} \mathrm{W}$ ), our plots were only a short walk trom the parking area, and fishermen often used the intertidal on weekends and holidays. Point Arguello (34 $33.19^{\prime}$ $\mathrm{N}, 122^{\circ} 37.27^{\prime} \mathrm{W}$ ) was most protected from harvesting, as it was within a harbor seal haul-out closure area and was strictly off-limits to all but researchers. Stairs $\left(34^{\circ} 43.88^{\prime} \mathrm{N}, 122^{\circ} 36.86^{\prime} \mathrm{W}\right)$ was near a civilian fishing beach. Purisima Point $\left(34^{\circ} 45.19^{\prime} \mathrm{N}, 120^{\circ} 38.14^{\prime}\right.$ $W$ ), a fishing area, was a 20 min hike from the nearest road and had been an abalone closure zone since 1988.

At each site, we established 3 permanent sampling plots where abalone were numerous. However, the lowest plot at Government Point $\left(51 \mathrm{~m}^{2}\right)$ could not be sampled during some surveys, so data from this plot were excluded from analyses. Total areas sampled were $123 \mathrm{~m}^{2}$ at Government Point, $59 \mathrm{~m}^{2}$ at Boathouse, $80 \mathrm{~m}^{2}$ at Point Arguello, $30 \mathrm{~m}^{2}$ at Stairs and $60 \mathrm{~m}^{2}$ at Purisima Point. The sizes and shapes of plots varied among sites according to abalone density or aggregation and local topography. For example, abalone at Stairs occurred in long, narrow cracks that were widely dispersed, so the plots were similarly arranged. In contrast, abalone at Government Point were most abundant in one area of deep tide pools, so the plots there were more rectangular and were contiguous.
We sampled most sites in winter (January to March) and fall (September to November) of each year from 1992 to 1995 by searching for abalone within permanently marked plots. We also sampled in spring (April to May) in 1995. Sampling did not begin at Purisima Point until fall 1993. Each time we sampled, we carefully searched plots and measured (to the nearest $5 \mathrm{~mm}$ ) shell lengths of all abalone found without removing the abalone from the substratum. We temporarily marked each abalone after measurement with a yellow crayon to avoid measuring it again. Sometimes it was necessary to estimate the lengths of abalone that were lodged deeply in cracks or were otherwise inaccessible. Because smaller abalone (<50 mm) often occurred behind larger individuals, this size class was potentially undersampled. Flashlights were necessary at some sites to search crack and crevice habitat. Starting in 1992 at Point Arguello and in 1993 at the rest of the sites, a haphazard selection of abalone were subjected to a pull-test to check for withering syndrome. The pull-test consisted of gently tapping the animal and then grasping the shell by hand and tugging. We replaced individuals pulled free. Healthy animals are extremely difficult to dislodge while weakened abalone readily detach from the rock (VanBlaricom et al. 1993). We also used this test in July 1995 to search for withering syndrome in areas between our permanent sites. Starting in 1992, empty shells were collected at Point Arguello and scored as fresh (if the interior of the shell was clean and shiny) or old. Size frequency data for live individuals at Point Arguello were pooled into an 'all sizes' category.

\section{RESULTS}

Abalone numbers declined at the 3 southern sites but not at the 2 northern sites (Fig. 2). Regression analysis of abalone number versus time revealed significant negative slopes for the 3 southern sites, whereas the 2 northern sites have significant positive slopes (Table 1).

The declines occurred in all size classes. The regressions for Boathouse and Government Point remain significant with sport harvestable (>127 mm) animals removed from the analysis (Table 1B). These trends are also evident when only animals larger than $50 \mathrm{~mm}$ are included (Table 1C), indicating that possible undersampling of small individuals does not affect the association. When only abalone smaller than $50 \mathrm{~mm}$ are included, the trend was still evident (Table 1D), although $\mathrm{p} \approx 0.06$ (2-tailed).

Abalone declined earliest at Government Point, their numbers dropping from 87 in winter 1992 to 47 in fall 1992. We were unable to sample at this site in winter 

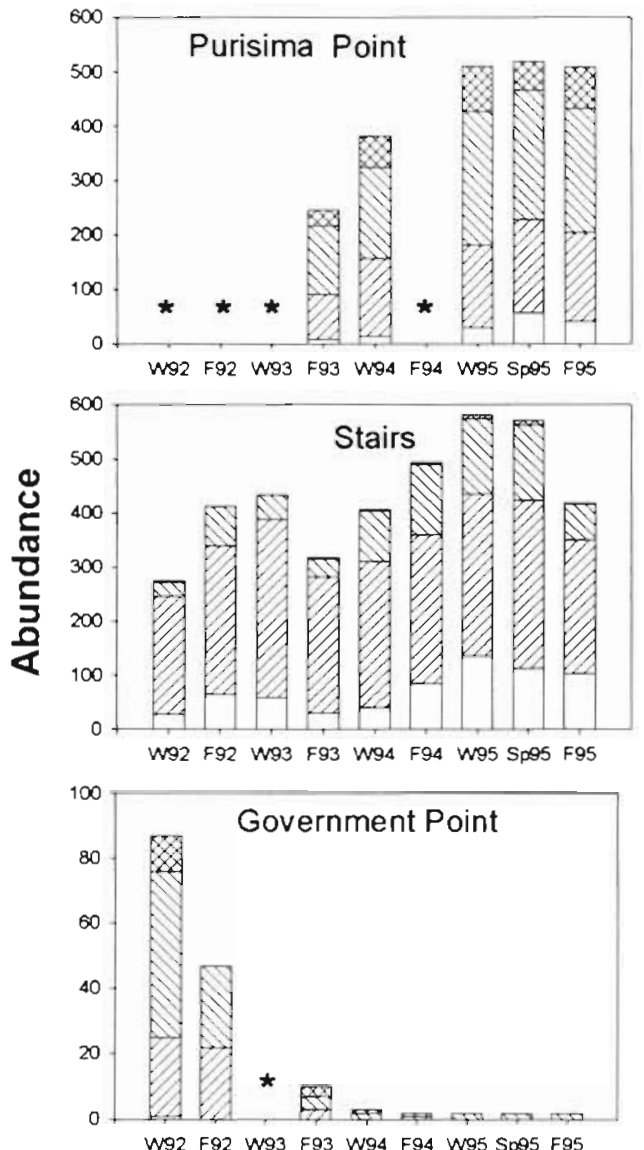
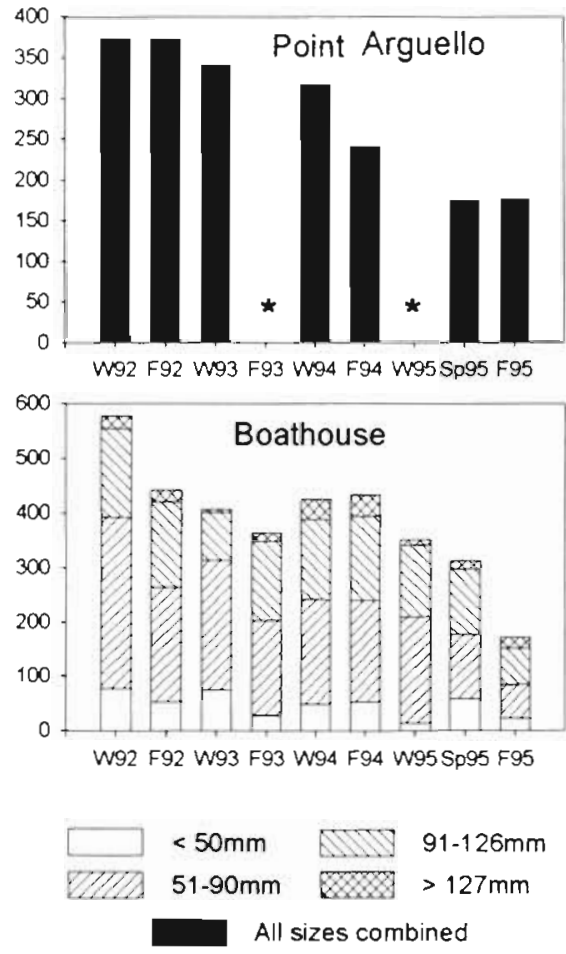

Fig. 2. Haliotis cracherodii. Densities and sizes of abalone sampled at 5 intertidal study sites. Sizes were not recorded at Point Arguello. W: samples laken in winter (January-March); Sp: spring (April-May); and F: fall (October-November). *Not sampled
1993 because of heavy surf. We found only 7 abalone in the vicinity by July 1995, 2 of which were within plot boundaries; all appeared healthy. Withering syndrome was not observed at this site, except for 1 weakened animal in January 1992.

Abalone abundance dropped at Boathouse in fall 1992, but then remained fairly constant until winter 1995. Field observations from fall 1993 revealed a few fresh empty shells, but all abalone subjected to a pull test appeared healthy. One deceased, withered animal was found in winter 1994. By February 1995, numbers had decreased but no withering syndrome-afflicted abalone were evident. However, California Department of Fish and Game wardens reported dead and dying abalone at this site in April 1995. In May, we found many fresh shells and pull-tests revealed that $3 \%$ of the population were weakened. During additional surveys in July, $7 \%$ of abalone tested showed clear signs of withering syndrome.

At Point Arguello, withering syndrome occurred in low frequencies from 1989 to 1993. However, abalone abundance in the plots did not decline until winter 1994, when the total number of abalone with withering syndrome and the fraction of shells that were fresh rather than old both increased (Fig. 3).
Abalone, especially smaller individuals (Table 1), increased at Stairs. Empty shells were rarely observed there. However, pull-tests in July 1995 revealed that $2.6 \%$ of abalone tested were withered, and lower densities were apparent in October 1995.

Black abalone numbers increased in 1993 and 1994 at the Purisima Point site, with no declines or other signs of withering syndrome. There were more legalsized animals here than at the other sites, and we found few empty shells.

There was a significant positive association between the change in density and the latitude of each site (Table 2, Fig. 4). Two other large, motile invertebrates, the owl limpet Lottia gigantea and seastar Pisaster ochraceus, were monitored at 3 of the sites and did not show similar changes in density with latitude (Table 2).

\section{DISCUSSION}

Our observations demonstrate that widespread mass mortality of black abalone is no longer confined to southern California. The black abalone declines moved northward from Point Conception. The progression from Government Point to Boathouse/Point 
Table 1 Haliotis cracherodii. Regression statistıcs for analysis of abalone number versus time. The model used was number = intercept + slope(time). Point Arguello was not included in the analyses of different sizes because the size of abalone in censused plots was not kept separate from those outside of the plots. $t$ : $t$-statistic

\begin{tabular}{|c|c|c|c|c|c|}
\hline Site & Intercept & Slope & $t$ & $r^{2}$ & $\mathrm{p}(2$-tail $\}$ \\
\hline \multicolumn{6}{|l|}{ A. All abalone sizes } \\
\hline Purisima Point & 54.3 & 11.69 & 4.659 & 0.88 & 0.019 \\
\hline Stairs & 318.1 & 4.88 & 2.600 & 0.49 & 0.035 \\
\hline Point Arguello & 401.0 & -4.84 & -6.053 & 0.88 & 0.002 \\
\hline Boathouse & 534.9 & -6.19 & -3.892 & 0.68 & 0.006 \\
\hline Government Point & 66.1 & -1.85 & -4.830 & 0.80 & 0.003 \\
\hline \multicolumn{6}{|c|}{ B. Abalone less than legal size $(127 \mathrm{~mm})$} \\
\hline Purisima Point & 48.6 & 10.04 & 4.494 & 0.87 & 0.021 \\
\hline Stairs & 317.5 & 4.77 & 2.574 & 0.49 & 0.037 \\
\hline Boathouse & 515.9 & -6.25 & -4.304 & 0.73 & 0.004 \\
\hline Government Point & 60.1 & -1.71 & -5.104 & 0.81 & 0.002 \\
\hline \multicolumn{6}{|c|}{ C. Abalone greater than $50 \mathrm{~mm}$} \\
\hline Purisima Point & 80.7 & 9.94 & 4.079 & 0.85 & 0.027 \\
\hline Stairs & 292.6 & 2.86 & 1.982 & 0.36 & 0.088 \\
\hline Boathouse & 463.6 & -5.21 & -3.428 & 0.63 & 0.011 \\
\hline Government Point & 65.6 & -1.84 & -4.861 & 0.80 & 0.003 \\
\hline \multicolumn{6}{|c|}{ D. Abalone less than $50 \mathrm{~mm}$} \\
\hline Purisima Point & 80.7 & 1.75 & 2.910 & 0.74 & 0.062 \\
\hline Stairs & 292.6 & 2.02 & 3.193 & 0.59 & 0.015 \\
\hline Boathouse & 463.6 & -0.98 & -2.227 & 0.42 & 0.061 \\
\hline Government Point & 65.6 & -0.02 & -2.238 & 0.46 & 0.067 \\
\hline
\end{tabular}

Table 2. Haliotis cracherodii, Lottia gigantea, Pisaster ochraceus. Change in species density (\%) between initial and final (winter 1995) samples for all sites. -: species not sampled at that site

\begin{tabular}{|lccc|}
\hline Site & Abalone & Owl limpets & Seastars \\
\hline Government Point & -0.97 & +0.22 & +1.91 \\
Boathouse & -0.70 & +0.20 & -0.39 \\
Point Arguello & -0.46 & - & - \\
Stairs & +0.52 & +0.43 & -0.53 \\
Purisima Point & +1.07 & - & - \\
\hline
\end{tabular}

Arguello, a distance of about $25 \mathrm{~km}$, took about 2 yr. The progression from Boathouse/Point Arguello to Stairs, a distance of about $23 \mathrm{~km}$, took about $1 \mathrm{yr}$. This progression is consistent with the advancement expected by an infectious agent (Lafferty \& Kuris 1993).

In April 1995, withering syndrome was detected in 14 of 29 abalone collected just west of the Cayucos Pier, an area $100 \mathrm{~km}$ to the north of our monitored sites (P. L. Haaker unpubl.). In November 1995, several withered abalone and numerous fresh shells were observed $4 \mathrm{~km}$ north at Cayucos Point (authors' pers. obs.). These observations suggest that the continued spread may not be limited to a gradual progression up the coastline. (Note that withering syndrome was recorded in Diablo Cove in 1988, but was limited to the

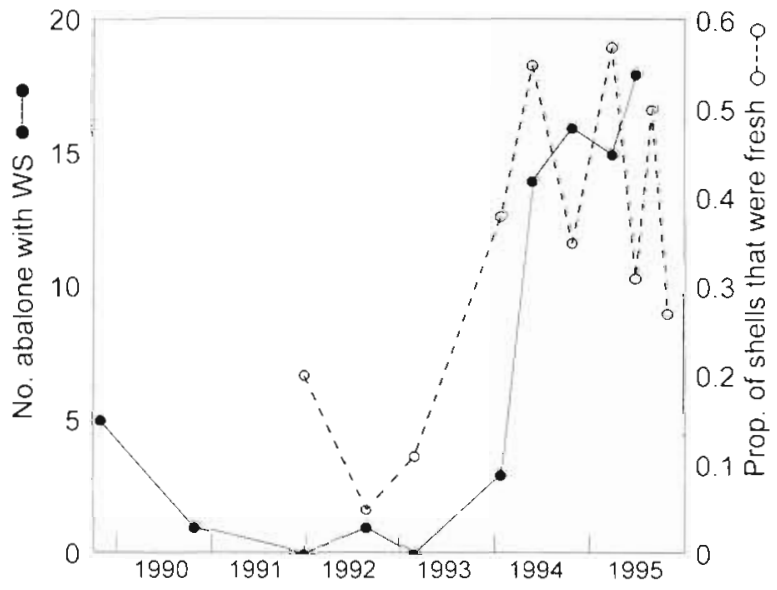

Fig. 3. Haliotss cracherodii. Occurrence of withering syndrome and fresh abalone shells at Point Arguello. Counts of abalone with withering syndrome were conducted within permanent plots and occasionally the surrounding area; since area searched was simlar but not identical during each census, data should be viewed as a general indication of trends. Shells were censused from the general area in and around the permanent plots

area near the Diablo Canyon Power Plant's thermal discharge.) Highly motile vectors of withering syndrome or localized current patterns might explain this discontinuous progression, but at this point these mechanisms remain speculative. Long-term monitoring at Año Nuevo (Tissot 1991), in San Mateo County, 


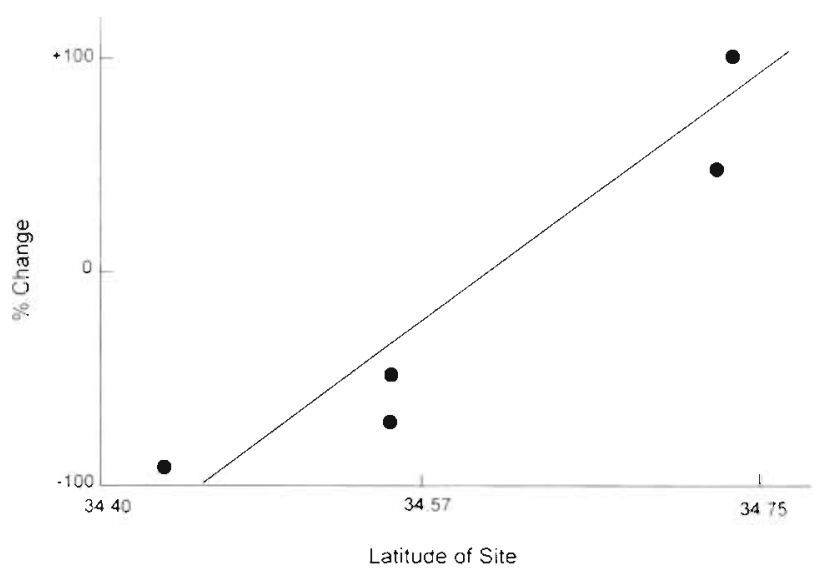

Fig. 4. Haliotis cracherodii. Change in abalone density as a function of latitude. Latitude (minutes and seconds) was converted to base 10 for the analysis. The regression equation [\% change $=656 \times($ latitude $)-22.719]$ is significant $(p=0.01)$ with

$$
\mathrm{r}^{2}=0.92
$$

California, will allow the detection of the spread of withering syndrome into the northern range of the species Unfortunately, we know little of the southward spread of withering syndrome beyond San Clemente Island and San Diego into Baja California, Mexico. Recent conversations with fishermen from Bahia Tortugas, Baja California Sur, Mexico, suggest that withering syndrome might have been present there around 1992. Black abalone apparently suffered unexplained mass mortalities at that time, and now only small numbers remain. Withered pink and green abalone have been observed by fishermen there as well.

The decline of black abalone in central California was generally associated with withering syndrome. At Stairs, abalone abundance began declining a few months after withered abalone were found. At Boathouse, there was an initial decline in fall 1992, after which abundances stabilized until winter 1995. The cause of the initial decline is not known, but it seems unlikely to have been due to withering syndrome because we found no direct evidence of this condition until 1 withered animal was found in winter 1994. On the other hand, the winter 1995 decline was clearly associated with withering syndrome, which was prevalent at Boathouse by March 1995. There is some question about the cause of the abalone decline at Government Point, since it was not accompanied by overt signs of withering syndrome. However, Government Point is very exposed, with exceptionally strong swell and surge (Littler 1978); an absence of empty shells suggests they are poorly retained at the site. Animals weakened by withering syndrome might not persist for long at this site. For example, the large swells in winter 1993 that prevented us from sampling could also have removed any afflicted abalone. Because abundance declined across all size categories, sport harvesting does not explain the changes we observed. Poaching seems unlikely due to the difficulty of gaining access to the site either by land or by boat. Sea otter predation remains a possibility, although exposed intertidal areas provide a partial refuge from otter predation (Ebert 1968, VanBlaricom \& Estes 1988). Seastars and owl limpets, the other large motile invertebrates monitored at Government Point, did not decline, so the decline in abalone was probably not due to a general disturbance such as sand burial, thermal stress or storms. The nature and timing of the decline, along with unambiguous evidence of withering syndrome at more northerly sites, suggest that withering syndrome was responsible for the loss of abalone at Government Point. Because the decline was evident as soon as we began monitoring, it is possible the population at this site began declining before 1992 .

Judging from past die-offs in the Channel Islands (Tissot 1995), we expect that densities at our sites will continue to drop. Recent declines at Boathouse and Point Arguello were only 40 to $45 \%$, whereas declines in the Channel Islands typically continued until more than $95 \%$ of the population had disappeared (Richards $\&$ Davis 1993). Abalone populations at our 2 northern sites have not yet declined markedly; however, individuals may be infected months before symptoms appear (Haaker et al. 1992). Moreover, substantial recruitment at Stairs during 1994 and winter 1995 (Fig. 2, Table 1D) enhanced densities and may have obscured effects of withering syndrome to some extent. Recruitment lessened the severity of declines at San Miguel Island for several years before the population finally collapsed (Richards \& Davis 1993). The sharp decline in the October 1995 sampling period and the results of the July 1995 pull tests suggest the beginning of a collapse at Stairs, although additional sampling is needed to confirm this.

At Government Point, as at the Channel Islands, less than $5 \%$ of the original population survived withering syndrome. Recovery of this population may be slow. Little is known about reproduction and early life history of black abalone, but in other abalone species recruitment may be patchy (Prince et al. 1987, McShane \& Smith 1991). Successful spawning may not occur at such low population densities because fertilization may only be successful when male and female abalone are within a few meters of each other (Breen \& Adkins 1980, Prince et al. 1988). Annual recruitment of juvenile black abalone at the Channel Islands declined steeply when adult populations dropped below half of initial densities (Richards \& Davis 1993). However, juvenile black abalone have recently been observed at some island sites previously devastated by withering syndrome (Tissot 1995, J. Altstatt \& D. Richards unpubl.). 
The significance of the black abalone decline may extend beyond this one species. Divers have reported shrunken red and pink abalone, and a 1995 survey of San Miguel Island by California Department of Fish and Game biologists found that 1 to $4 \%$ of red abalone had visual signs of withering syndrome (Friedman 1995). Thus, existing abalone fisheries and mariculture operations may be threatened by the continued geographic spread of withering syndrome. The ecological ramifications of the decline of black abalone are not yet known, but the decline of a dominant space holder might be expected to alter the structure of the surrounding intertidal community. For example, increases in the densities of colonial sand castle worms Phragmatopoma californica and vermetid snails Serpulorbis squamigerus appear to result from the removal of black abalone (Douros 1985, Lafferty \& Kuris 1993, Miller \& Lawrenz-Miller 1993, Richards \& Davis 1993). We are currently investigating these effects as withering syndrome spreads northward.

Acknowledgements. We thank Debbie Boylen, Jay Carroll, Noel Davis, Mary Elaine Dunaway, Maurice Hill, Dan Martin, Mike McCrery, Laird McDonald, Mark Pierson, Dan Richards, Ian Taniguchi, Lynette Vesco, Melissa Wilson and many other volunteers for their help in the field. We also thank Tim King and the Bixby Ranch Corporation and Brad Lendberg and the Cojo-Jalama Ranch for access to Government Point, and Vandenberg Air Force Base, especially Nedra Delima, Col. Franklin J. Blaisdell, USAF, Base Commander, Col. Louis D. Van Mullem, Jr, USAF, Environmental Division, Major Frank A. Wells, Jr, USAF and the staft at the Recreation Center for access to the remaining sites. This work was funded by Minerals Management Service Cooperative Agreement No. 14-35-0001-30620 and the California Department of Fish and Game.

\section{LITERATURE CITED}

Ambrose RF, Engle JM, Raimondi PT, Wilson M, Altstatt JM (1995) Rocky intertidal and subtidal resources: Santa Barbara County mainland. Final Report to the Pacific Outer Continental Shelf Region of the Minerals Management Service. OCS Study MMS 95-0067

Breen PA, Adkins BE (1980) Spawning in a British Columbia population of Northern Abalone, Haliotis kamtschatkana. Veliger 23:177-179

Cox KW (1962) California abalones, family Haliotidae. Calif Fish Game Fish Bull 118:1-133

Davis GE, Richards DV, Haaker PL, Parker DO (1992) Abalone population declines and fishery management in southern California. In: Shepherd SA, Tegner MJ, Gusman del Proo SA (eds) Abalone of the world: biology, fisheries, and culture. Proc 1st Int Symp Abalone. University Press, Cambridge, p 237-249

Douros WJ (1985) Density, growth, reproduction and recruitment in an intertidal abalone: effects of intraspecific competition and prehistoric predation. MSc thesis, University of California, Santa Barbara

Douros WJ (1987) Stacking behavior of an intertidal abalone: an adaptive response or a consequence of space limita- tion? J Exp Mar Bıol Ecol 108:1-14

Ebert E (1968) A food habits study of the southern sea otter. Enhydra lutris nereis. Calif Fish Game 54:33-42

Friedman CS (1995) Current status of withering syndrome. Abalone Focus 1:1-2

Gardner GR, Harshbarger JC, Lake JL, Sawyer TK, Price KL. Stephenson MD, Haaker PL, Togstad HA (1995) Association of prokaryotes with symptomatic appearance of withering syndrome in black abalone Halrotis cracherodii. J Invert Pathol 66:111-120

Haaker PL, Henderson KC, Parker DO (1986) California abalones. California Marine Resources Leaflet 11 University of California Sea Grant Marine Advisory Program Cooperatuve Extension, La Jolla

Haaker PL, Richards DV, Friedman CS, Davis GE, Parker DO, Togstad HA (1992) Mass mortality and withering syndrome in black abalone, Haliotis cracherodii, in California. In: Shepherd SA, Tegner MJ, Gusman del Proo SA (eds) Abalone of the world: biology, fisheries, and culture. Proc 1st Int Symp Abalone. University Press, Cambridge, p 214-224

Lafferty KD, Kuris AM (1993) Mass mortality of abalone Haliotis cracherodii on the California Channel Islands: tests of epidemiological hypotheses. Mar Ecol Prog Ser 96: $239-248$

Littler MM (1978) Biological features of rocky intertidal communities at Government Point, Santa Barbara County, California. In: Littler MM (ed) The annual and seasonal ecology of southern California subtidal, rocky intertidal and tidepool biotas in the southern California Bight. Bureau of Land Management, US Department of the Interior, Washington, DC, 1.1.12

McShane PE, Smith MG (1991) Recruitment vanation in sympatric populations of Haliotis rubra (Mollusca: Gastropoda) in southeast Australian waters. Mar Ecol Prog Ser 73:203-210

Miller AC, Lawrenz-Miller SE (1993) Long-term trends in black abalone, Haliotis cracherodii Leach 1814, populations along the Palos Verdes Peninsula, California. J Shellfish Res 12:195-200

Parker DO, Haaker PL, Togstad HA (1992) Case histories for three species of California abalone, Haliotis corrugata, $H$. fulgens, and H. cracherodii. In: Shepherd SA, Tegner MJ Gusman del Proo SA (eds) Abalone of the world: biology, fisheries, and culture. Proc 1st int Symp Abalone. University Press, Cambridge, p 384-394

Prince JD, Sellers TL, Ford WB, Talbot SR (1987) Experimental evidence for limited dispersal of haliotid larvae (genus Haliotis; Mollusca: Gastropoda). J Exp Mar Biol Ecol 106: $243-263$

Prince JD, Sellers TL, Ford WB. Talbot SR (1988) Confirmation of a relationship between the localized abundance of breeding stock and recruitment for Haliotis rubra Leach (Mollusca: Gastropoda). J Exp Mar Biol Ecol 122:91-104

Richards DV, Davis GE (1993) Early warnings of modern population collapse in black abalone Hallotis cracherodii, Leach 1814 at the California Channel Islands. J Shellfish Res 12:189-194

Shepherd SA, Breen PA (1992) Mortality in abalone: its estimation, variability and causes. In: Shepherd SA, Tegner MJ, Gusman del Proo SA (eds) Abalone of the world: biology, fisheries, and culture. Proc 1st lnt Symp Abalone. University Press, Cambridge, p 276-304

Steinbeck JR, Groff JM, Friedman CS, McDowell T, Hedrick RP (1992) Investigations into a mortaluty among populations of the California black abalone, Haliotis cracherodii, on the central coast of California, USA. In: Shepherd SA, 
Tegner MJ, Gusman del Proo SA (eds) Abalone of the world: biology, fisheries, and culture. Proc 1st Int Symp Abalone. University Press, Cambridge, p 203-213

Tegner MJ (1989) The Calıfornia abalone fishery: production. ecological interactions, and prospects for the future. In Caddy JF (ed) Scientific approaches to management of invertebrate stocks. Wiley, New York, p 401-420

Tissot BN (1988) Mass mortality of black abalone in southern California. Am Zool 28:69A

Tissot BN (1990) El Nino responsible for decline of black abalone off southern California. Hawaiian Shell News 38: $3-4$

Tissot BN (1991) Geographic variation and mass mortality in the black abalone: the roles of development and ecology

This article was submitted to the editor
PhD dissertation, Oregon State University, Corvallis Tissot BN (1995) Recruitment, growth, and survivorship of black abalone on Santa Cruz Island following mass mortality. Bull South Calif Acad Sci 94:179-189

VanBlaricom GR, Estes JA (eds) (1988) The community ecology of sea otters. Ecology Series 65. Springer Verlag, New York

VanBlaricom GR, Ruediger JL, Friedman CS, Woodard DD, Hedrick RP (1993) Discovery of withering syndrome among black abalone Haliotis cracherodii Leach, 1814, populations at San Nicolas Isiand, Califorma. J Shellfish Res 12:185-188

Young PH (1964) Some effects of sewer effluent on marine lite. Calif Fish Game 50:33-41

Manuscript first received: February 15, 1996

Revised version accepted: June 28, 1996 